\title{
Epidermolysis bullosa acquisita treated with rituximab
}

\author{
Sónia Raquel Mendes, Inês Coutinho, José Carlos Cardoso
}

Dermatology Department, Coimbra University Hospital, Coimbra, Portugal

\section{Correspondence to} Dr Sónia Raquel Mendes; soniaraquel23@gmail.com

Accepted 2 July 2021

\section{DESCRIPTION}

We report the case of a 69-year-old male patient, observed for vesiculobullous lesions involving the oral mucosa (figure 1), trunk and extremities. There were also more evolved lesions with crusted surface and erythematous cicatricial plaques covered by milia cysts.

Histology revealed a cell-poor subepidermal blister (figure 2), and direct immunofluorescence showed linear deposition of IgG and C3 along the dermoepidermal junction.

ELISA detected circulating antibodies against collagen VII, confirming the diagnosis of epidermolysis bullosa acquisita (EBA).

He was initially medicated with methylprednisolone $24 \mathrm{mg}$ and dapsone $50 \mathrm{mg}$ every day in combination with topical therapy. For lack of response, dapsone was replaced by azathioprine, initially $50 \mathrm{mg}$ once a day, then $50 \mathrm{mg}$ two times a day and then reduced to the initial dose due to side effects. Due to the ineffectiveness of the therapy and the side effects associated with corticosteroids and azathioprine, he initiated rituximab therapy, having performed four cycles with slight improvement and transient stabilisation of the clinical picture, without reaching complete remission.

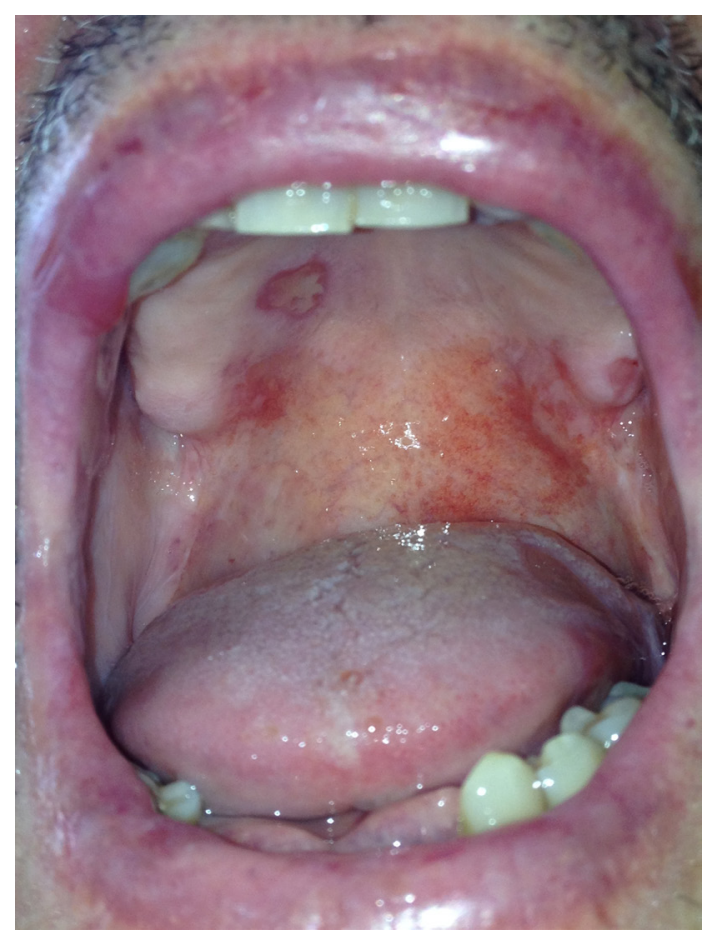

Figure 1 Vesiculobullous lesions involving the oral mucosa.

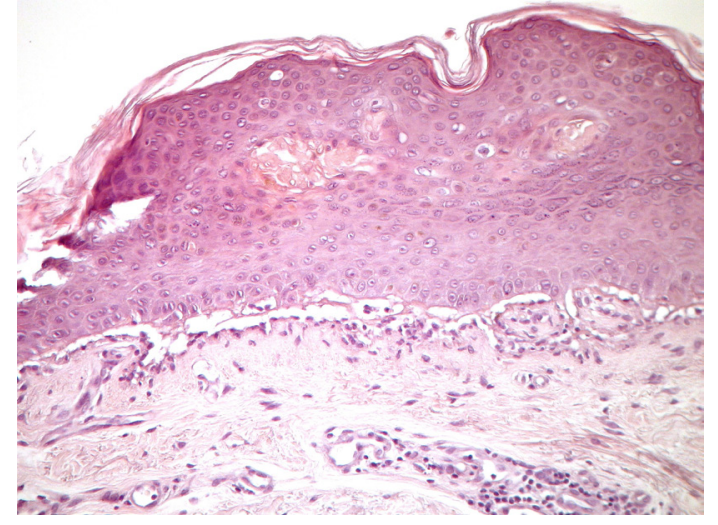

Figure 2 Histology showing a subepidermal detachment with scant inflammatory infiltrate (H\&E $\times 100)$.

EBA is a rare acquired, mucocutaneous, subepidermal, autoimmune blistering disease, which results in vesicle and bullae formation on the skin and erosions on the mucous membranes. ${ }^{1-5}$ EBA can evolve with cicatricial mucosal involvement, leading to respiratory, ocular and/or digestive sequelae with important morbidity. ${ }^{1-3}$ It usually appears in adulthood (with a median age of 50 years), with no known predilection to sex. ${ }^{1-3}$ Clinically, it can present with numerous phenotypes, though the most common are the mechanobullous and inflammatory variants; EBA includes various distinct clinical manifestations resembling bullous pemphigoid, Brunsting-Perry pemphigoid or cicatricial pemphigoid. ${ }^{1-4}$ There is an association with HLA-DR2 and the patients have autoantibodies against collagen VII, an integral component of anchoring fibrils responsible for attaching the dermis to the epidermis. ${ }^{1-3}$ It may be associated with other diseases, such as diabetes mellitus, thyroiditis, Crohn's disease, systemic lupus erythematosus, lymphomas, pernicious anaemia and autoimmune thrombocytopenia. ${ }^{1-3}$ The importance of the differential diagnosis of this entity with other subepidermal autoimmune bullous dermatoses, such as bullous pemphigoid, linear adult IgA dermatosis and bullous systemic lupus erythematosus, is highlighted. ${ }^{1-4}$ Diagnosis is established by having a consistent clinical presentation, direct immunofluorescence and autoantibodies against collagen VII. ${ }^{1-3}$ Once the diagnosis is established, however, it is challenging to find optimal treatment for the patient. ${ }^{1-5}$ Multiple drugs have been used in the treatment of EBA, resulting in varying degrees of response; the most frequently reported agents include systemic corticosteroids, antiinflammatory and immunosuppressive agents. ${ }^{1-5}$ 
Currently, treatment is often unsatisfactory; however, some success has been achieved with colchicine, dapsone, azathioprine, photopheresis, plasmapheresis, infliximab, rituximab and intravenous immunoglobulins. ${ }^{1-5}$ EBA, especially in its classic form, is characterised by poor response to immunosuppressive therapies. ${ }^{1-5}$ There have been developments in newer treatment modalities that have achieved some success. ${ }^{1-5}$ Rituximab, an anti-CD20 monoclonal antibody, alone or in combination with other agents, showed potential to induce long-term remission in EBA resistant to other treatments. ${ }^{1-5}$

\section{Learning points}

Few cases of epidermolysis bullosa acquisita (EBA) have been described in the literature.

- Diagnosing EBA is often difficult because of the variety of clinical presentations that may overlap with other blistering diseases, such as bullous pemphigoid and cicatricial pemphigoid.

Rituximab was shown to be effective in this case of EBA previously resistant to other therapies.
Contributors SRM (first author): acquisition and analysis of data, planning, conducting, conception and design of the article, as well as revision and fina approval. IC: acquisition of data and final approval. JCC: acquisition of data, revision and final approval.

Funding The authors have not declared a specific grant for this research from any funding agency in the public, commercial or not-for-profit sectors.

Competing interests None declared.

Patient consent for publication Next of kin consent obtained.

Provenance and peer review Not commissioned; externally peer-reviewed.

\section{REFERENCES}

1 Santi CG, Gripp AC, Roselino AM, et al. Consensus on the treatment of autoimmune bullous dermatoses: bullous pemphigoid, mucous membrane pemphigoid and epidermolysis bullosa acquisita - Brazilian Society of Dermatology. An Bras Dermatol 2019:94:33-47.

2 Koga H, Prost-Squarcioni C, Iwata H, et al. Epidermolysis bullosa acquisita: the 2019 update. Front Med 2018;5:362.

3 Kridin K, Kneiber D, Kowalski EH, et al. Epidermolysis bullosa acquisita: a comprehensive review. Autoimmun Rev 2019;18:786-95.

4 Kridin K, Ahn C, Huang WC, et al. Treatment update of autoimmune blistering diseases. Dermatol Clin 2019;37:215-28.

5 Bevans SL, Sami N. The use of rituximab in treatment of epidermolysis bullosa acquisita: three new cases and a review of the literature. Dermatol Ther 2018:31:e12726.

Copyright 2021 BMJ Publishing Group. All rights reserved. For permission to reuse any of this content visit https://www.bmj.com/company/products-services/rights-and-licensing/permissions/

BMJ Case Report Fellows may re-use this article for personal use and teaching without any further permission.

Become a Fellow of BMJ Case Reports today and you can:

- Submit as many cases as you like

- Enjoy fast sympathetic peer review and rapid publication of accepted articles

- Access all the published articles

- Re-use any of the published material for personal use and teaching without further permission

Customer Service

If you have any further queries about your subscription, please contact our customer services team on +44 (0) 2071111105 or via email at support@bmj.com.

Visit casereports.bmj.com for more articles like this and to become a Fellow 